\title{
A MARRIED WOMAN'S RIGHT OF ACTION FOR LOSS OF CONSORTIUM IN ALBERTA
}

\author{
STELLA J. BAILEY*
}

\begin{abstract}
The history of married women's right of action for loss of consortium is reviewed. Analysis of the present state of the law lends to suggestions for reform, including abolition of the ac. tion when founded on enticement.
\end{abstract}

\section{INTRODUCTION}

In Alberta today, a married woman is in the same position as her husband in having a cause of action against a third party for loss of consortium, ${ }^{1}$ whether it be caused by physical injury to the spouse by the third party, or by enticement or harbouring, and also has the same right of action as her husband against a third party who has committed adultery with him. It is only since October 30,1973 that a married woman has enjoyed this position, by virtue of The Attorney-General Statutes Amendment Act. ${ }^{2}$ Prior to that time, it had been held by the Supreme Court of Alberta that she did have a right of action for loss of consortium by reason of enticement. ${ }^{3}$ However, in another case it was also held that she had no right of action for loss of consortium where her husband was injured by a third party. ${ }^{4}$ Where a third party committed adultery with her husband or harboured him, an argument could have been made that a married woman in Alberta could maintain an action against that person; however, the situation was not clear. By enacting The Attorney-General Statutes Amendment Act, therefore, the Government of Alberta removed any doubt as to whether these actions could be brought and also gave a married woman a right of action where her husband was injured, either intentionally or negligently, by a third party.

The purpose of The Attorney General Statutes Amendment Act seems to have been to create equality in some seventeen statutes by making specific provisions in them applicable to both women and men, as opposed to one or the other. As a result of this attempt to reduce sex discrimination in the law, the Alberta government provided a married woman with a right of action for loss of consortium however caused without giving serious thought as to why she should have this right of action or why indeed either spouse should have it in modern times. It is the purpose of this paper to determine whether the reforms instituted by the Government were the most appropriate, considering the alternative of abolition of the right of action for both husband and wife. Before considering that question, the law prior to October 30,1973 will be set out in order to demonstrate that the changes that were made were long overdue.

- B.A., LL.B., University of Alberta; articling with the Supreme Court of Alberta and Oughton \& Davis in Calgary.

1. In present days consortium has been said to include: companionship, love, affection, comfort, mutual services, sexual intercourse Kungl v. Schiefer [1901] O.R. 1 at 7), though in earlier times, it seems to have been restricted to services, as this paper will illustrate.

2. S.A. 1973, C.61, ss. 5(4), 5(16).

3. Wener v. Davidson (1970) 75 W.W.R. 693; affirmed (1971) 17 D.L.R. (3d) 232.

4. Duorkin v. Stuart [1971] 2 W.W.R. 70 (Alta. A.D.). 


\section{LAW PRIOR TO 1973}

In 1927 The Domestic Relations Act ${ }^{b}$ gave a husband a right of action for damages against a person who committed adultery with his wife, enticed her away, harboured her or physically injured her, either intentionally or negligently. By enacting these provisions, the Government merely embodied in statute a right of action which the husband had at common law. One can only conjecture why a wife was not given a similar right of action. Perhaps the Government was influenced by the judicial thinking of the time as contained in Lellis v. Lambert ${ }^{6}$, a decision of the Ontario Court of Appeal which denied a married woman such a right of action for reasons that could have been criticized even at that time. In fact, the reasoning had been criticized four years earlier in Quick v. Church ${ }^{7}$, the first Canadian case in which a married woman brought an action for loss of her husband's consortium and was successful.

\section{A. Lellis v. Lambert}

In Lellis v. Lambert, which overruled Quick v. Church, it was held that neither at common law nor under The Married Women's Property Act was an action available to a married woman against another woman for alienation of affections or for damages for adultery. The case cited in Lellis v. Lambert as clear authority for the common law position was Lynch v.Knight. ${ }^{8}$ However, when one considers the judgments in that case as to a married woman's right of action for loss of consortium, dicta only since the case was decided on remoteness of damage, one can see that not only do they conflict but that they provide no legal reason as to why a married woman should not have a right of action for loss of consortium.

To set out briefly the judgments in Lynch v. Knight, Lord Chancellor Campbell stated that loss of consortium was not a pecuniary loss and that it might be a loss to the wife which the law would recognize. However, he indicated that a married woman could not maintain an action for criminal conversation because she should condone her husband's infidelity though he need not condone hers. Lord Wensleydale stated that there was no precedent or authority to support a wife's right of action for loss of consortium. He then went on to say that the wife's interest in the marital consortium is of a different character than that of her husband so that she suffers only loss of his society and affections and not of her maintenance when there is an interference in the conjugal relationship while he suffers a pecuniary loss, that of loss of services.

In Lellis v. Lambert, further support is provided for the position that a married woman could not maintain an action for loss of consortium at common law. Therein it is indicated that a woman was unable to maintain such an action for the reason that she had no legal interest in her husband's person or property and therefore could not sue for an injury to him. Blackstone stated it in the following way: ${ }^{\ominus}$

The inferior has no kind of property in the company, care, or assistance of the superior as the superior is held to have in those of the inferior, and therefore the inferior can suffer no loss or injury. The wife cannot recover damages for beating her husband, for she has no separate interest in anything during her coverture.

5. S.A. 1927, C.5, ss. $13,31,32,34$.

6. (1897) 24 O.A.R. 653.

7. (1893) 23 O.R. 262 (Q.B.).

8. [1861-73] All E.R. Rep. 2344 (H.L.).

9. Blackstone, Commentaries on the Laws of England (1768) at 142-3. 
It is also pointed out in Lellis v. Lambert that, before The Married Women's Acts, a married woman could not sue alone and the damages recovered when the husband sued alone or together with his wife became the property of the husband. To have allowed such recovery by the husband who had allowed himself to be enticed to commit adultery, would, in the words of Mr. Justice Maclennan have shocked all sense of justice and decency. ${ }^{10}$

The case of Phillips v.Barnet ${ }^{11}$ is then cited to demonstrate that even if the procedural obstacle were removed, a married woman could not successfully maintain an action against her husband because she and her husband are one person in law. In that case, it was held that a wife could not, after divorce, sue her former husband for the assault and battery he committed upon her during coverture.

The Married Women's Property Act ${ }^{12}$ did not affect the common law position; it was stated in Lellis v. Lambert that this Act gave a married woman the right to sue and be sued with respect to her separate property and her contracts in respect of that property and that it did not give her a general right to sue and be sued as if she were a feme sole.

When one considers the reasons which are presented in Lellis v. Lambert against a married woman having a right of action for loss of consortium, one can see that they can be easily rebutted. There is no precedent to support a wife's right of action for loss of consortium because a married woman, before the passage of the Married Women's Property Acts in the 1880's, would not have brought such an action because she would have had to join her husband in the suit and the damages which she would have recovered would have become his. Thus, there would have been no point in her suing. However, that does not mean that a cause of action did not exist for her.

As for there being a difference in the interests that the husband and wife each had in the marital consortium, even in the 1600's, with the decisions in Guy v.Livese ${ }^{13}$ and Hyde v.Scyssor ${ }^{14}$, it was clear that what the husband, in an action for loss of his wife's consortium, was being compensated for was loss of company, not services. In Guy v. Livesey it was stated that

the action is not brought in respect of the harm done to the wife, but it is brought for the particular loss of the husband, for that he lost the company of his wife, which is only a damage and loss to himself, for which he shall have this action, as the master shall have for the loss of his servant's service.

The words in Hyde v. Scyssor are similar. Although in both cases an analogy is made between the husband's action and that of a master, the courts do hold that the loss of a wife's company (as opposed to her services) is a damage for which the husband should be compensated.

With respect to the wife not having proprietary rights in the person or property of her husband, reference must be made to a 1745 case, Winsmore v. Greenbank $k^{16}$, in which it was held that it is a tortious act to persuade a mar-

10. (1897) 24 O.A.R. at 669 .

11. [1876] 1 Q.B. 436 .

12. R.S.O. 1887 , C. $132,8.3(2)$.

13. (1618) 79 E.R. 428.

14. (1619) 79 E.R. 462.

15. (1618) 79 E.R. at 428.

16. (1745) 125 E.R. 1330. 
ried woman to live apart from her husband without justification and that the loss of her consortium which results as a conseqence of that act is damage which is recognized by the law.

Of this case it has been said that since the action there was brought not in trespass but on the case, the decision in favour of the husband was not based on his proprietary rights over his wife and so marks an important change in the basis of the general consortium action ${ }^{17}$. In setting forth this proposition, reference is made to Mr. Justice Isaacs' judgement in Wright v. Cedzich where he states: ${ }^{18}$

In Winsmore v. Greenbank an action was brought on the case for enticing away and detaining the plaintiff's wife, for loss of 'the comfort and society' of the wife and her aid and assistance in his domestic affairs,' etc. This was obviously not founded on any dominion or right to possession, giving rise to trespass $v i$ et armis, actual or fictitious. It was founded on the principle even then well established ... that 'the law will never suffer an injury and a damage without a remedy'; that the tortious act followed by damage, in that case the loss of 'the comfort and assistance of his wife' made the cause of action.

Notwithstanding the change in law which Winsmore v. Greenbank represents, it is disputed whether a husband ever had those extensive powers over his wife that it is suggested he did. Although the marital relationship was properly characterized as a guardianship profitable to the husband until the enactment of the Married Women's Property Acts, which established a separate estate in the married woman, this was not to say that a husband and wife did not have reciprocal rights and duties in marriage. With respect to this relationship, it has been stated that: ${ }^{10}$

If we look for any one thought which governs the whole of this province of law, we shall hardly find it. In particular, we must be on guard against the common belief that the ruling principle is that which sees an 'unity of person' between husband and wife ... a consistently operative principle it can not be.

We do not treat the wife as a thing or as somewhat that is neither thing nor person.... The husband is the wife's guardian: - that we believe to be the fundamental principle; and it explains a great deal, when we remember that guardianship is a profitable right.... But... we can not explain the marital relationship as being simply the subjugation of the wife to the husband's will.... To this we must add that there is a latent idea of community between husband and wife which can not easily be suppressed.

The fictional unity of husband and wife was arguably abolished in Ontario in 1884 with the enactment of The Married Women's Property Act ${ }^{20}$ since that Act gave a wife the right to sue her husband for the protection and security of her own separate property. Therefore, at the time of Lellis v. Lambert, the argument that husband and wife are one person in law may have been improperly put forward to deny a married woman a right of action for loss of consortium. In Alberta, although The Married Women's Act was enacted in 1936, it was earlier that the unity of husband and wife doctrine was impliedly abrogated: in 1886, a married woman was given all the rights and liabilities of a feme sole in respect of land acquired by her ${ }^{21}$ and in 1889 she was given the same rights and liabilities in respect of her personal property. ${ }^{22}$

17. Baker, "Consortium and the Alleged Emancipation of the Married Woman", (1951-3) $2 A n$. nual L. Rev. (W. Aust.) at 81-2.

18. Wright v. Cedzich (1930) 43 C.L.R. 493 at 515 (H.C. Aust.).

19. Pollock and Maitland, as cited by Williams. "Consortium and the Common Law." (1963) 15 S.C.L. Rev. at 817 .

20. S.O. 1884, C.19.

21. The Territories Real Property Act, The North-West Territories Act 1886, C. 25, s. 13.

22. North-West Territories Ordinance 1889 , No. 16. 
At the time of Lellis v. Lambert, the Ontario Married Women's Property Act provided that ${ }^{23}$

[a]married woman shall be capable of entering into and rendering herself liable in respect of and to the extent of her separate property on any contract, and of suing and being sued in all respects as if she were a feme sole.

This provision was amended in $1913^{24}$ so that "in all respects" was preceded by "either in contract or in tort or otherwise", the words of the Ontario Act of 1884 and of the English Act of 1882. Although Mr. Justice Osler in Lellis v. Lambert did not think that the meaning of the paragraph was affected by the change of expression, it was by reason of the revision that, forty-nine years later, the Ontario Court of Appeal in Applebaum v. Gilchrist ${ }^{25}$ found that it was not bound by the decision in Lellis v. Lambert. The words "either in contract or in tort or otherwise" in the 1913 revision were interpreted in Applebaum v. Gilchrist as giving a married woman a general right to sue without joining her husband. The earlier provision was interpreted in Lellis v. Lambert as giving a married woman the right to sue only with respect to her separate property and contracts. It might be noted that Chief Justice Armour, four years earlier in Quick v. Church, did not give the same restricted meaning to the relevant provision of The Married Women's Property Act as did the court in Lellis v. Lambert.

In Alberta, The Married Women's Act which was enacted in 1936 provided that a married woman shall be capable of suing and being sued either in contract or in tort or otherwise and in all respects as if she were a feme sole $e^{28}$ and thereby gave her a general right to sue without joining her husband.

Although the reasons given in Lellis v. Lambert for denying a married woman a right of action for loss of consortium had no foundation in law, the decision stood for forty-nine years until the case of Applebaum v. Gilchrist came before the Ontario Court of Appeal. During that time, six reported actions ${ }^{27}$ were brought by married women for loss of consortium against other women as well as parents. Only one of these was successful when the Court in Sheppard v. Sheppard ${ }^{28}$ distinquished Lellis v. Lambert, restricting it to actions for criminal conversation which the husband may bring but which a wife cannot. However, there were two actions brought in Lellis v. Lambert, one for damages for adultery and the other for alienation of affections. Thus the distinction made in Sheppard v. Sheppard is not clear.

In considering Applebaum v. Gilchrist and other more recent cases where married women have brought actions for loss of consortium, the cases will be discussed under the following headings: enticement, intentional and negligent injury, criminal conversation, harbouring.

23. R.S.O. 1887, C.132, s. 3(2).

24. S.O. 1913, C. $29,8.4(2)$.

25. [1946] O.R. 695.

26. S.A. 1936, C. 23, s. 2(c).

27. Lawry v. Tuckett-Lawry (1901) 2 O.L.R. 162 (Weekly Crt.); Weston v. Perry (1909) 14 O.W.R. 956 (C.A.); Sheppard v. Sheppard (1922) 51 O.L.R. 520 (Weekly Crt.); Sequin v. Laferriere (1924) 25 O.W.N. 607 (H.C.); Talmage v. Talmage (1928) 62 O.L.R. 209 (Chambers); Barks v. Done [1933] O.R. 784 (Weekly Crt.).

28. (1922) 51 O.L.R. 520 (Weekly Crt.). 


\section{B. Enticement}

In Applebaum v. Gilchrist ${ }^{29}$ in which the Ontario Court of Appeal found that it was not bound by Lellis v. Lambert, it was held that a married woman does have an action for damages for loss of her husband's society and services against a woman who wrongfully entices and procures her husband to cease cohabitating and consorting with her. The two grounds for finding that it was not bound by Lellis v. Lambert were that: 1) The Married Women's Property Act was amended in 1913 so as to provide a married woman with a general right to sue and be sued; 2) The cause of action in Lellis v. Lambert was not the same.

As to whether a married woman has a common law right to her husband's consortium, a violation of which would give her a right of action, the Court answered that question in the affirmative. In dealing with the question, two different approaches were taken by Chief Justice Robertson and Mr. Justice Laidlaw who formed the majority of the Court.

Chief Justice Robertson indicated that Lynch v.Knight left open the question whether a married woman has a legal right to consortium. He also pointed out that when Lynch v. Knight was decided, the legal position of a husband and a wife was different in that a double standard prevailed so that it was not a compelling argument to say that since a husband had a legal right to consortium so should a wife. This double standard was that a husband could obtain a divorce on proof of his wife's adultery while she had to prove bigamy, cruelty, or desertion in addition to adultery.

Chief Justice Robertson found authority to support a wife's cause of action for loss of consortium in recent English decisions and the adoption of the principle contained in them by text-writers of authority. However, even without judicial opinion supporting a cause of action by a wife, he stated that the availability of such an action would be warranted by the many social changes which have occurred, tending towards equality of the sexes before the Courts.

Mr. Justice Laidlaw first considered the reasoning behind the husband's action for loss of consortium against a person who enticed away his wife, and concluded that the husband had an action because a tort had been committed, there being an interference with the husband's right to the consortium of his wife. Since there is no real and substantial distinction between the rights to consortium which the husband and wife possess in law, then it cannot be successfully argued, he said, that a wife should have no right of action where her rights to her husband's consortium are violated. In considering that no distinction exists between a husband's and a wife's rights to consortium, he stated that it is not doubted that, at common law, marriage gave a husband a right of guardianship over his wife but, even so, each assumed similar obligations to each other. He indicated that marriage did not extinguish all of a woman's rights; she merely could not enforce them without joining her husband as a party to the proceedings.

$\mathrm{Mr}$. Justice Laidlaw disagreed that a married woman's right of consortium is of a different character and of a lesser quality than that of her husband. He stated that, in light of subsequent discussion and judicial opinions, it cannot be said that Lynch v. Knight supports that argument or the one that a wife 
has no action for loss of consortuum. He also indicated that it is well settled that the element of consortium upon which an action such as the one before the Court is based is not loss of services but loss of company and society.

After Applebaum v. Gilchrist was decided, when married women in Ontario $^{30}$, British Columbia ${ }^{31}$ and Alberta ${ }^{32}$ brought actions for loss of consortium caused by enticement, they were successful, provided they proved the allegations made.

In Alberta it was in September 1970 that an action was first brought by a married woman for loss of her husband's consortium, caused there by the defendant's enticement. This case, Wener v. Davidson ${ }^{38}$, was unlike $A p$ plebaum v. Gilchrist and those cases which followed it in principle, in that Alberta legislation at the time gave a husband a right to sue for loss of consortium but did not give a wife that same right. Therefore Mr. Justice Kirby of the Supreme Court of Alberta had to first consider whether the provisions of The Domestic Relations Act ${ }^{34}$ giving a husband that right constituted an exclusive and comprehensive code. The provisions which he considered comprised Part V of The Domestic Relations Act, entitled "Loss of Consortium":

8.32. A person who, without lawful excuse, knowingly and wilfully persuades or procures a woman to leave her husband against the will of the husband, whereby the husband is deprived of the society and comfort of his wife, is liable to an action for damages by the husband.

s.33. A husband also has a right of action for damages against a person who, without lawful excuse, knowingly receives, harbours and detains his wife against the will of the husband.

8.34. No action lies under section 33 if

(a) the plaintiff and his wife were living apart by agreement, or were judicially separated, when the act of the defendant took place, or

(b) the plaintiff has been guilty of cruelty to his wife, and the defendant harbours the wife from motives of humanity, or

(c) the defendant has reasonable grounds for supposing that the husband has been guilty of cruelty to his wife, and harbours the wife from motives of humanity.

s.35. (1) Where a person has, either intentionally or by neglect of some duty existing independently of contract, inflicted physical harm upon a woman and thereby deprived her husband of her comfort and society, that person is liable to an action for damages by the husband in respect of deprivation.

(2) The right of the husband to bring the action referred to in subsection (1) is in addition to, and independent of, any right of action that the wife herself has or any right of action that the husband in her name has for the injury inflicted upon his wife.

Whether these sections constituted a complete code was at issue in Fediuk v. Lastiwk ${ }^{35}$, a case in which a husband was unsuccessful in claiming damages for having been deprived of the consortium of his wife. The main argument on behalf of the plaintiff husband was that the adultery admitted by the defendant in itself constituted an actionable loss of consortium as defined in Part V of The Domestic Relations Act. Mr. Justice McBride of the Appellate Division of the Supreme Court of Alberta disagreed, concurring with the trial judge that Part $V$ is a complete code on the subject of loss of consortium. Since the plaintiff was not within the provisions of Part V, he was unsuccessful even though he would have had a good cause of action at common law.

30. Frampton v. Whiteman [1954] O.R. 32 (H.C.); Brydon v. Abernethy [1951] O.W.N. 428.

31. Judge v. Smith (1962) 30 D.L.R. (2d) 521 (B.C.S.C.).

32. Wener v. Davidson (1970) 75 W.W.R. 693 (Alta. S.C.).

33. Id.

34. R.S.A. 1955, C.89, 8s. $32-35$.

35. (1957) 21 W.W.R. 74, affirmed (1958) 24 W.W.R. 481. 
Mr. Justice Johnson, with Mr. Justice MacDonald concurring, also upheld the decision of the trial judge. He concerned himself with the meaning of consortium, saying that the specific provisions under Part V, "Loss of Consortium", refer only to the loss of the comfort and society of the wife and not to the loss of servitium or sexual relations which were included in the common law definition of "consortium". In Fediuk v. Lastiwka, the plaintiff refused to have sexual relations with his wife on learning of her adultery although she remained in the home and performed her other "wifely duties". Mr. Justice Johnson stated that if he were wrong and the words "society and comfort" were wide enough to express all of the consortium, he would prefer to follow the reasoning of those Lords in Best v. Samuel Fox and Co ${ }^{38}$ who held that a plaintiff has no cause of action for loss of consortium unless there has been a total loss, as opposed to loss of only one element such as sexual relations.

In Wener v. Davidson, Mr. Justice Kirby referred to the majority judgments set out above but preferred the words of the dissenting Mr. Justice Porter on the question whether The Domestic Relations Act constitutes an exclusive and comprehensive code. The latter stated that: ${ }^{37}$

There is no word in the Domestic Relations Act depriving a husband of any right which he had at common law, nor is there any word depriving a wife of the action she may have. To hold that it consititutes a code excluding rights which, but for the statute would have existed, requires that the Court should find in the statute either express words removing existing rights of action, or words from which it is necessary to infer that the Legislature meant to deprive citizens of existing rights of action.

Mr. Justice Kirby adopted those words in so far as they apply to the rights of a wife. He also stated that he concurred with the view of Chief Justice Milvain of the Trial Division who heard the application in Chambers to strike out the wife's statement of claim on the ground that it disclosed no cause of action. Chief Justice Milvain had stated that: ${ }^{88}$

The Act is a code only with respect to the rights of a husband. If she (a wife) had, at common law, the rights now sought to be enforced, the Act did not destroy them.

Having decided that The Domestic Relations Act did not codify the law with respect to a married woman's right of action for loss of consortium, Mr. Justice Kirby then considered whether she had such a right at common law. He first referred to the view expressed in Lellis v. Lambert and Wright v. Cedzich that she did not. However, he preferred the decision in Applebaum v. Gilchrist which he considered in some detail. Since that case has been discussed above, it will not be set out here.

Mr. Justice Kirby compared the words of section 2(c) of the 1955 Alberta Married Women's Act ${ }^{30}$ with those of section 3(1) of the Ontario Act ${ }^{40}$ and found them to be the same. Therefore he concluded that a married woman in Alberta had a common law right of action for loss of consortium caused by enticement and the The Married Women's Property Act removed the procedural obstacle to the exercise of that right.

As of April 8, 1971 when the Appellate Division of the Supreme Court of Alberta dismissed the appeal from Mr. Justice Kirby's decision, ${ }^{11}$ it was

36. [1951] 2 K.B. 639, affirmed [1952] A.C. 716.

37. (1970) 75 W.W.R. at 696.

38. Id., at 697 .

39. S.A. 1955, C. 193, s. 2(c).

40. R.S.O. 1937, C. 209, s. 3(1).

41. (1971) 17 D.L.R. (3d) 232. 
clear that a married woman in Alberta had a right of action for loss of consortium against a woman who enticed away her husband.

Therefore, when the Government of Alberta amended The Domestic Relations Act, to give a married woman a right of action for loss of consortium caused by enticement, it was merely embodying in statute what has already been settled by the courts. However, that was not the case where loss of a husband's consortium was caused by intentional or negligent injury, or by criminal conversation or harbouring.

\section{Intentional and Negligent Injury}

Prior to 1973, there had been only two reported Canadian cases where women claimed damages for loss of consortium caused by the negligence of a third party. In Drewry v. Towns, ${ }^{42}$ a Manitoba case heard in 1951, a married woman sued for loss of consortium in addition to claiming damages under The Trustee Act and The Fatal Accidents Act, when her husband, a gratuitous passenger in a motor vehicle, was killed when it collided with an unlighted stationary truck which the defendant had negligently parked on the highway. The Manitoba Queen's Bench, citing Baker v. Bolton ${ }^{43}$ as authority, held that this action for loss of consortium could not be maintained because it was not a cause of action surviving the deceased.

The other case in which a married woman brought an action for loss of her husband's consortium due to the negligence of a third party was Dvorkin v. Stuart 44 , an Alberta case heard in December, 1970. In Dvorkin v. Stuart the husband was injured in an automobile collision and subsequently experienced traumatic neurosis which evidenced itself in mental anguish, fear, anxiety and the anticipation of imminent calamity. As a result of the neurosis, he lost his capacity to enjoy life, suffered a complete personality change and became sexually impotent.

In Dvorkin v.Stuart the question whether the wife could recover for loss of consortium was apparently not argued to any extent before Mr. Justice Cullen. He was referred to Best v. Samuel Fox and Co ${ }^{45}$ in which it was held by the House of Lords that a married woman has no cause of action for loss or impairment of consortium where her husband is injured by the negligent act or omission of a third person. In coming to that decision, the House of Lords distinguished between a claim for loss of consortium in an action based on enticement (saying that such an action is available to the wife) and one againsta third party whose negligence has caused physical injury.

Mr. Justice Cullen in Dvorkin v. Stuart accepted that there was a distinction and held that the plaintiff wife had no claim for loss of consortium.

Although there are no reported cases of women bringing actions for loss of their husbands' consortium caused by intentional injury, it is arguable that, on the basis of the reasoning in Best v. Samuel Fox \& Co., they would not be successful. The same distinction could be made between loss of consortium caused by enticement and that caused by intentional injury to the spouse as was made between loss of consortium due to enticement and that due to

42. [1951]2 W.W.R. (N.S.) 217 (Man. Q.B.).

43. (1808) 170 E.R. 1033.

44. [1971] 2 W.W.R. 70 (Alta. A.D.).

45. [1952] A.C. 716. 
negligent injury - namely, that there can be no liability for loss of consortium without knowledge of the marital relationship. It is no answer to this distinction to say that it does not apply where a third party has injured a wife and her husband is suing for loss of consortium, for the court could merely say, as it did in Best v. Samuel Fox \& Co. that though the husband's right of action in modern times is anomalous, there is no reason to extend this anomaly.

Notwithstanding that a distinction might be between loss of consortium caused by enticement and that caused by negligent or intentional injury, to allow recovery to the husband in both cases but not to the wife is unjust. The Government of Alberta remedied this situation in 1973 when it gave a married woman a right of action for loss of consortium, however caused. However, if the husband's action is indeed anomalous, as stated by Lord Goddard in Best v. Samuel Fox and Co., rather than giving the wife a similar right of action, the Government should have abolished the husband's right of action against a third party who injures his spouse.

\section{Criminal Conversation}

In Alberta, no married woman has ever reportedly claimed damages against the woman who has committed adultery with her husband. Since that is the case, it is necesary to consider cases in other provinces in which women have brought such actions. In that way, suggestions may be presented as to Alberta's position prior to 1973.

The first action brought by a woman in Canada for loss of consortium was for that caused by adultery. In that case, Quick v. Church ${ }^{46}$, heard in 1893, the woman was successful, but the decision was later overruled by the Ontario Court of Appeal in Lellis v. Lambert. There, alienation of affections was also pleaded. That case has already been fully considered and will not be reconsidered here.

Frampton v. Whiteman ${ }^{47}$ is the only other reported Canadian case prior to 1973 in which a married woman brought an action for loss of consortium caused by adultery. More specifically, criminal conversation was the action brought. The plaintiff in the case also claimed damages for alienation of her husband's affections, a ground on which she was successful since Mr. Justice McRuer of The High Court of Ontario felt that he was bound by the Ontario Court of Appeal's decision in Applebaum v. Gilchrist. However, the latter decision was found to have no application with respect to the action for criminal conversation; the reasoning was that the decision in Applebaum v. Gilchrist was based on loss of consortium while the cause of action for criminal conversation is based on adultery, loss of consortium being incidental since adultery must be proved if the action is to be maintained.

Having restricted Applebaum v. Gilchrist to actions for enticement, $\mathbf{M r}$. Justice McRuer first considered whether a wife had, prior to 1792 , a cause of action for criminal conversation at common law. The year 1792 is the relevant date in that the Property and Civil Rights Act of Ontario provides:8

46. (1893) 23 O.R. 262 (Q.B.).

47. [1954] O.R. 32 (H.C.).

48. R.S.O. 1950, C. 293. 
In all matters of controversy, relative to property and civil rights, resort shall be had to the laws of England as they stood on the 15th day of October, 1792 , as the rule for the decision of the same,... except 80 far as such laws and rules have been since repealed, altered, varied, modified or affected .... by any Act of the late Province of Upper Canada, or of the Province of Canada, or of the Province of Ontario, still having the force of law in Ontario.

Should the wife have had an action prior to 1792 , then Mr. Justice McRuer could have found that the right of action became enforceable when The Married Women's Property Act was passed and the plaintiff might have been successful.

Referring to various authorities, Mr. Justice McRuer indicated that ${ }^{49}$

[a]l the old cases emphasize that a man has a right of action in trespass against anyone who, with or without her consent, has violated his wife. Underlying and involved in this is the right of a husband to have his wife inviolate. One of the incidents of this is that a husband is not to be exposed to the obligation to provide for children who may not be his own.

He then considered the decision in Lellis v. Lambert in some detail, stating that the judgements of the Court of Appeal in that case are clear and convincing that a wife had no right of action at common law for criminal conversation against her husband's paramour. Other authorities are cited as additional support for the proposition that the wife has no action against the woman who has committed adultery with her husband.

Mr. Justice McRuer's concluding words provide the two main reasons why he denied a married woman a right of action for loss of consortium caused by criminal conversation. The first involved the possible consequences of the adultery, namely that: ${ }^{50}$

The adultery of the wife might impose a spurious issue upon the husband, which he might be called upon to dedicate a part of his fortune to educate and provide for; whereas no such injustice could result

to his wife from the adultery of a married man.

The second is that he could not ignore the Property and Civil Rights Act, the relevant section of which has been set out above.

In imagining what the law relating to a married woman's right to recover damages for adultery might have been in Alberta prior to 1973, it is the applicability of these reasons to the Alberta situation that must be examined. To deal with the second reason first, Alberta has a similar provision to that in the Ontario Property and Civil Rights Act. It provides that the laws of England relating to civil and criminal matters as they existed on July 15, 1870 shall be in force in the Territories except as they have been repealed, altered, varied, modified or affected by an Act of the Parliament of the United Kingdom applicable to the Territories, or the Parliament of Canada, or by an ordinance of the Lieutenant Governor in Council or of the Legislative Assembly. ${ }^{61}$ Therefore in Alberta the question would be whether a woman had a right of action for criminal conversation at common law prior to $1870 .^{32}$

49. [1954] O.R. at 36 .

50. Id., at 37-9, Mr. Justice McRuer citing Lord Eldon.

51. The North-West Territories Act 1886, N.W.T. Ordin. 1915, s. 11 as adopted by The Alberta Act, S.C. 1905, C. 3, s. 16.

52. It might be noted that prior to 1870 , The Matrimonial Causes Act of $1857,20 \& 21$ Vict.C. 85, had abolished the action for criminal conversation in England and had given a husband a right to claim damages from the adulterer. The wife was not given a similar right of action. However, the argument could be made that the Act was not a comprehensive code and that the wife's right was to be found in the common law. 
Although Mr. Justice McRuer in Frampton v. Whiteman found that a wife had no cause of action for criminal conversation at common law, the authorities are certainly not clear that it was so and it could have been argued that she did. However, even if one were successful in making a convincing argument on that point, how could one have rebutted Mr. Justice McRuer's first reason, as to the possible consequences of the adultery. One writer provides the following response to the argument that a wife's infidelity may impose the support of another man's child on the husband while a husband's infidelity would not impose a similar burden on the wife: ${ }^{53}$

True as this may be, yet a husband's infidelity may impose financial burdens on him of which the wife is wholly ignorant, depriving her of luxuries which, although not legally entitled to, were nevertheless showered upon her previous to the enticement of her husband.

This response, though weak, is one that could have been made and it, in fact, becomes stronger when one considers that the wife may be deprived even of necessaries by reason of her husband's infidelity should he be financially unable to meet the maintenance obligations to his legitimate and illegitimate families.

A better argument concerning the consequences of adultery would have been formulated by considering the husband's right of action in Alberta.

In 1907 the Supreme Court Act expressly provided that the Supreme Court of Alberta shall have jurisdiction to entertain an action for criminal conversation and that the law applicable to such actions in Alberta shall be the same as it was in England prior to the abolition of the action there. ${ }^{54}$ In considering the principles on which damages were assessed in an action for criminal conversation, it can be seen that the conseqences of the adultery of the wife were a factor: ${ }^{55}$

The action lies [in criminal conversation] for the injury done to the husband in alienating his wife's affections, destroying the comfort had from her company, and raising children for him to support and provide for; and as the injury is great, so the damages given are commonly very considerable .... Damages are based on two main considerations: first, the value of the wife to the husband, including benefit derived from her fortune, her assistance in business, her capacity as a housekeeper and ability generally in the home, and benefit derived from her society and affection and her general qualities as a wife and mother; secondly, compensation to a husband for injury to his feelings and honour, and hurt to his matrimonial and family life.

It has been indicated that, if the defendant were able to prove that the wife had no value to her husband and that there was no shock to his feelings of injury to his family life, the court might find that the husband suffered no damages notwithstanding the proof of adultery. ${ }^{56}$

The statutory cause of action for criminal conversation which was available to the husband remained in Alberta for twenty years. In 1927 it was abolished by the Alberta Domestic Relations Act which gave a husband a statutory cause of action to recover damages from a person who committed adultery with his wife ${ }^{57}$. The 1927 Domestic Relations Act also gave a husband three other statutory causes of action for loss of consortium.

53. Kanigsberg, "Domestic Relatons - Loss of Consortium of Husband," (1932) 10 Can. Bar. Rev. at 549.

54. S.A. 1907, C.3, s.18.

55. Fediuk v. Lastiwka (1958) 12 D.L.R. (2d) at 433-4.

56. Payne, "Tortious Invasion of the Right of Marital Consortium," (1968) 8 J. Family Law at 43.

57. S.A. 1927, C.5, 8.13 . 
From 1927 on, therefore, a husband could, merely on proof of his wife's adultery, recover damages from the wife's adulterer. He no longer had to prove loss of value of his wife or injury to his feelings, honour, or family life. By statute then, it was the act of adultery which was the basis of the action and not the consequences which may have resulted from it, whether these were loss of consortium and injury to honour or another man's children to support. How then could it have reasonably been said that a wife should not have the same right of action for damages as her husband against a person who commits adultery with him? Is not the act of adultery the same whether committed by the husband or the wife?

One can only guess whether the arguments set out above would have convinced a court prior to 1973 to allow a married woman to recover damages for adultery. The decision is Frampton v. Whiteman may well have been followed by the Alberta courts, in which case the 1973 amendments to The Domestic Relations Act represented a necessary change in the law.

\section{E. Harbouring}

There have been no Canadian cases in which married women have claimed damages for loss of consortium caused by harbouring. Therefore it is difficult to say what the law in Alberta might have been prior to 1973. In Winchester v. Fleming, Mr. Justice Devlin stated that ${ }^{58}$

the reason why harbouring was considered objectionable was because it interfered with the economic process by which a wife, refused food and shelter elsewhere than in the matrimonial home, would eventually be forced to return to it.

Supposedly, it could have been argued that this method of effecting a matrimonial reconciliation was applicable to husbands as well and that therefore a married woman should have the same right of action for loss of consortium caused by harbouring as did her husband. It does seem that an action for harbouring, unlike one for criminal conversation, is similar to an action for enticement in that it is the loss of the consortium that is the basis of the action. Therefore, should a case of harbouring have come before the courts, it is suggested that the same objections as those put forward to deny a wife a cause of action for loss of consortium caused by enticement would have been presented and successfully overcome.

In 1973 a married woman in Alberta was given a statutory right of action for loss of consortium, one which her husband had enjoyed since 1927. There was no valid reason for denying her such a right of action for so long. However, rather than merely extending a right of action for loss of consortium to the wife, it is submitted that the Government should have considered abolishing the right of action for both spouses. It is that question that will now be examined.

\section{REFORM OF THE LAW}

In considering the reform of the law relating to loss of consortium, a distinction will be made between those actions which do not necessarily involve a tort committed against the spouse and those which do. The first group includes enticement, criminal conversation and harbouring and the second consists of the action for loss of consortium caused by injury to the spouse by a third party, either intentionally or negligently. In the latter case, both spouses have a separate cause of action, one suing for the personal injury and the other for the loss of consortium. 


\section{A. Enticement, Criminal Conversation, Harbouring}

Arguments have been presented by various writers both in favour of and against total abolition of the causes of action based on non-tortious conduct to the spouse. To consider those arguments in favour of abolition first, one writer put it in the following way: ${ }^{58}$

Whether or not we accept notions of permanently vested rights of affection and service between two individuals, it seems evident that, where a third person does succeed in gaining the affections of another's spouse to the extent that the marriage is more or less effectually broken up, little unity could have existed between the spouses at the material time and that the conduct of an interloping third person might have been "the straw that broke the camel's back"; any one of a myriad of things might have achieved the same result.

That same sentiment, among others, is expressed by the Ontario Law Reform Commission which in 1969 recommended that the actions of enticement and harbouring of a spouse and the action of criminal conversation should be abolished. ${ }^{\circ}$ In coming to that decision, the Ontario Law Reform Commission considered the proposals suggested by the English Law Commission with respect to claims for damages for adultery and actions for enticement. The English Law Commission recommended abolition of both actions for the following reasons: ${ }^{\text {i1 }}$

Both treat the wife as the husband's chattel, and lend themselves to blackmail especially when there is collusion between husband and wife. Both encourage perjury when there is collusion between the wife and her seducer. But in some respects, the action for damages for adultery is more objectionable than that for enticement. The latter at least recognises that the claim is based on the fact that the husband, because of the defendant, has lost his wife. The former purports to compensate the husband for the fact that the defendant has had sexual intercourse with the wife. This rather barbarous theoretical basis of the action has adverse practical consequences in that the parties are able to place one another in a humiliating position and when proceedings are brought they tend to create great bitterness between the parties.

The Ontario Law Reform Commission similarly found the laws relating to enticement, criminal conversation and harbouring to be uncivilized, unworkable and outmoded. That body stated that: ${ }^{62}$

The placing of a price on sexual conduct between a person's spouse and a third person belongs to a past age. This is particularly so when one considers that the participating spouse has normally consented to and may have even encouraged the conduct .... Whatever society's view of extra-marital sexual conduct may be, these laws prove no solution.... The only real protection a marriage can have must be based on each partner to the marriage acting responsibily to the other.

These arguments in favour of abolishing actions for damages against third parties who have harboured, enticed away or committed adultery with spouses are very persuasive. However, before recommending abolition of these actions in Alberta on the basis of them, it is necessary to consider the arguments which have been presented against abolition.

One writer, William M. Kelly, presents his case for the retention of causes of action for intentional interference with the marital relationship by setting

59. Haines, "Family Law - Loss of Consortium - Distinction Between Enticement and Alienation of Affections - A Revival of the Forms of Action," [1961] U. of T. Fac. of Law Rev. at 148.

60. It should be noted that legislation has been passed by the Government of Ontario putting this recommendation of the Ontario Law Reform Commission into effect as well as that dealing with loss of consortium caused by injury to the spouse, which will be considered in the next section of this paper (The Family Law Reform Act, S.O. 1978, C. 2, s. 69, s. 60).

61. English Law Commission, Working Paper No. 9: Matrimonial and Related Proceedings Financial Relief (1967) at para. 132.

62. Ontario Law Reform Commission, Report on Family Law: Torts (1969) at 97. 
up the arguments which have been used in favour of abolition and then rebutting them. ${ }^{68} \mathrm{He}$ first deals with the argument that ${ }^{64}$

collusion between husband and wife presents not only the danger of outright blackmail but also the possibility of actual recovery of damages followed by a "reconciliation" of differences that never in fact existed.

To this argument he replies that there is no reliable evidence that such abuse is prevalent. Besides, procedural limitations and judicial discretion can be used as adequate safeguards against abuse in this area as they have been in other areas of the law.

As for the argument that actions for enticement, harbouring and criminal conversation are anachronistic, being based on the notion that the husband had a proprietary interest in his wife, he states that this sort of criticism may be misdirected. He continues: ${ }^{65}$

Even though the actions were originally designed to protect a fictive right and reflected a nowantiquated view of the relation between the sexes, they have in the modern era taken on a very different and worthwhile function - that of providing a remedy for injuries of a highly sensitive nature while discouraging intentional disruptions of families.

The next argument that he deals with is that interferences with marriages are not consciously planned but rather just happen. His response is that, even though the intermeddler may not interfere by design, that is not to say he does not know what he is doing. He then states that, considering the tendency for casual acquaintances to develop into marital disruptions, there is good reason for retaining the causes of action as warnings of the magnitude of the consequences which may follow.

The fourth argument that he considers is one directed at maligning the character of the plaintiff in the action. This attack on the plaintiff may apparently be carried out in one of two ways. The first is as follows: "decent people don't call attention to their marital difficulties", the implication being that the plaintiff's motive is strictly mercenary and vindictive ${ }^{68}$ The answer which is given to this attack is that if a plaintiff has a right to continued harmony in marriage then he should also have an opportunity to vindicate any intrusion upon it. The second attack on the plaintiff's character is one which implies that if his marriage is so shaky that it is vulnerable to attacks made by outsiders, then it is his fault and he should not be allowed to complain. The response to this attack which is given is that: :7 $^{2}$

It ignores the fact that the malice and intensity of the outsider's assault upon the marriage may also vary. Even a relatively "good" marriage may be susceptible to, for instance, a Don Juan.

The final argument which is considered is that relating to the assessment of damages. This argument is broken down into three parts as follows: 1)it is difficult to valuate emotional and mental distress; 2 ) as a result, juries tend to consider the wrongdoer's conduct rather than the actual injury to the plaintiff; 3 ) even if valuation is not difficult, it is undesirable to commercialize the marital relationship. Each of these is easily rebutted by Kelly. In response to the first point, he states that: ${ }^{88}$

63. Kelly, "The Case for Retention of Causes of Action for Intentional Interference with the Marital Relationship", (1972) 48 Notre Dame Lawyer at 430-433.

64. Id., at 430.

65. Id., at 431 .

66. Id.

67. Id.

68. Id., at 432 . 
An analysis of cases dealing with the emerging tort of intentional infliction of emotional distress provides ample evidence that monetary valuation of strictly psychic injuries can be made.

As to the second point, the question which he puts is whether total abolition is the answer to this problem. As for the "fear of commercialization" argument, he states that damage awards have never been claimed to fully and perfectly compensate for injuries, but only serve as approximate compensation.

Having rebutted the arguments which have been used in favour of abolishing actions for enticement, criminal conversation and harbouring, Kelly concludes that none of them has overcome $e^{89}$

the force of the basic tenet of our jurisprudence that one who suffers a substantial injury at the hands of another is entitled to a remedy if one can be rationally framed.

However, he recognizes that there are inadequacies in the law and makes some suggestions for reform. The most fundamental reform measure suggested is the abolition of the action for criminal conversation, stating that it is outdated in light of society's changing moral attitudes.

What changes in society's mores require the abolitions of the action of criminal conversation but not that of enticement or alienation of affections? He states: ${ }^{70}$

There is growing evidence that extramarital sexual activity is becoming not only more common but more acceptable, apparently even to the partners to the marriage.

Thus he would retain the actions for enticement and alienation to protect the sanctity of marriage and the functional importance of the family in our society though he would abolish the action for criminal conversation.

Having considered the arguments in favour of abolishing actions for enticement, harbouring and criminal conversation and the successful rebuttal of them, it seems that the essential difference between the abolitionists and the non-abolitionists lies in their response to the following question: Should the law protect the marital relationship from injury? The abolitionists answer this question in the negative stating that the only real protection that a marriage can have will be found in each party to the marriage acting responsibly to the other. The non-abolitionists, on the other hand, answer the question in the affirmative, believing that the responsibility for protection of marriage and the family lies with the State and not with the parties to the marriage contract themselves. Even though Kelly very ably rebuts the arguments which have been used in favour of abolition, one cannot agree with his conclusion, if one believes that a lasting marriage depends on the partners to it and not on the law. Somehow it seems strange that Kelly recommends that the action for criminal conversation should be abolished for the reason that extra-marital sexual activity is becoming more common and acceptable but that the actions for enticement and alienation must be retained. Surely if spouses are to be free to engage in sexual activity with third parties, they should also be free to decide when they want a more meaningful relationship with those third parties, without fear of impending suits. By recommending the retention of actions for enticement and alienation, Kelly is suggesting that the spouse who has been enticed away is a mindless creature who cannot be held responsible, even in part, for the dissolution of the marital relation-

69. Id., at 433 .

70. Id. 
ship and that the third party is totally at fault. It is submitted that one cannot reasonably operate on this premise.

In the writer's opinion, a marriage will endure when both parties to it make a conscious effort to make it a lasting relationship. It is the parties to the marriage themselves and not the possible sanction of the law that must discourage third parties from interfering with the marital relationship. It is for this reason therefore that the writer recommends that in Alberta those causes of action which are based on non-tortious conduct to the spouse should be totally abolished so that neither spouse can sue a third party for adultery, enticement or harbouring.

It has been stated that: $:^{71}$

If the matrimonial relationship is of any social value - which nobody would deny in the common law world - both parties to that relationship have an interest in its maintenance and freedom from external interference, deliberately indulged in for the purpose of disruption. That being so, their interest should be protected by the law in the appropriate way, by granting rights of action where such interference has occurred.

The writer disagrees with that statement only to the extent that is not the law but the parties to the marriage themselves who must protect it.

\section{B. Intentional and Negligent Injury}

It has been recommended above that neither husband nor wife should have a right of action against a third party who entices away, harbours or commits adultery with his or her spouse. Whether the same recommendation should be made with respect to loss of consortium caused by injury to the spouse is the question which will now be considered.

In 1963 the English Law Reform Committee recommended that the husband's action for loss of consortium caused by injury to his wife should be abolished and replaced by an action which would be available to either spouse for reasonable expenses incurred as a result of the injury to the other. ${ }^{72}$ The reason for abolition was that the action for loss of consortium is anachronistic. However, not to replace it with an action such as that suggested would lead to injustice. The reasonable expenses would include ${ }^{73}$

medical and nursing expenses and all other costs properly incurred in consequence of the injury, such as reasonable visits to hospital and the reasonable cost of providing domestic help to replace the injured partner

as well as "any earnings lost as a result of action reasonably taking in consequence of the injury. ${ }^{74}$

The Ontario Law Reform Commission in 1969 agreed that the husband's common law action for loss of his wife's society and services should be abolished for the reason that is based on the husband's proprietary interest in his wife, a premise which is no longer valid. ${ }^{76}$ Like the English Law Reform Committee, it recommended that, in the place of the husband's common law action, there should be a statutory right available to either spouse to enable them to claim damages for certain losses when the other spouse is wrongfully injured by a third person. The Ontario Law Reform

71. Fridman, "Consortium as an "Interest" in the Law of Torts," (1954) 32 Can. Bar. Rev. at 1072.

72. Ontario Law Reform Commission, supra n. 62 at 100.

73. Id.

74. Id.

75. Id., at 101. 
Commission too would restrict losses to pecuniary ones, with damages being awarded on a similar basis to that under the Ontario Fatal Accidents Act. ${ }^{78}$ It might be noted that one of the Commissioners advocated that legislative action should permit the awarding of both pecuniary and nonpecuniary losses. This same argument is put forward by one writer who first considers whether an action for unintentionally caused loss has a place in modern society. ${ }^{77}$ She believes that it does - to protect the interests of spouses to a subsisting marriage. These interests which are the same for both women and men include: companionship, love, affection, comfort, mutual services and sexual intercourse. Having decided that both spouses should have a right of action for unintentionally caused loss of consortium, she considers whether such a right of action should award damages for both non-pecuniary and pecuniary losses.$^{78}$ Citing the passage which follows from an American case, she concludes that it should, at least as long as recovery is allowed in other cases of non-pecuniary loss: ${ }^{70}$

It is . . . contended that the "sentimental" damages such as diminution of the value of her husband's society and affection and the deprivation of sexual relations and the attendant loss of child-bearing opportunity are too personal, intangible and conjectural to be measured in pecuniary terms .... This argument has no merit. The logic of it would also hold a jury incompetent to award damages for pain and suffering. Money is a poor substitute for the loss of an only child or the pain resulting from serious injuries. Likewise it cannot truly compensate a wife for the destruction of her marriage, but it is the only means to compensate for the loss suffered and to symbolize society's recognition that a culpable wrong - even if unintentional - has been done.

As for the problem of the possibility of abuse of such a right of action, she suggests joinder of both spouses' actions to overcome the problem of double recovery as well as to enable the court to take into consideration any damages which have been awarded to the husband for the impairment of his abilities to provide support to his wife. ${ }^{80}$

In the previous section of this paper, it has been recommended that it is not the law but the partners to a marriage who must protect it from the invasions of third parties. Should the parties to the marriage fail in their responsibility, they will find no compensation for their loss in the courts. But such a recommendation is not unduly harsh, for discouraging adulterers, harbourers and "enticers away" (as well as the female counterpart of those) is in the spouses' control. But what of the situation where a third party injures a spouse either intentionally or through negligence and as a result the other spouse suffers a loss of any or all of those elements which have been said to comprise the consortium, namely: companionship, love, affection, comfort, mutual services, and sexual intercourse? Surely one cannot say that the prevention of the injury was in the control of the injured person. It is for this reason that the writer does not find it illogical to recommend the abolition of those causes of action for loss of consortium which do not involve a tort committed against the spouse while on the other hand recommending the retention of the action for loss of consortium caused by injury to the spouse.

76. Id., at 110 .

77. West, "Per Quod Consortium Amisit: New Life for an Old Tort?", (1975) 33 U. of T. Fac. of Law Rev. at 88.

78. Id., at 89 .

79. Id., at $89-90$ citing from Millington v. Southeastern Elevator Co. (1968) 239 N.E. (2d) 897 at 902 (N.Y.C.A.).

80. Id., at 89 . 
Though the action for loss of consortium caused by injury, which has been available only to the husband, has its historical basis in a concept which is no longer valid today, that is not to say that such an action available to both spouses has no value today. It has been stated that: ${ }^{81}$

The interests that spouses have in the security of the marriage have been termed "relational interests" and it is argued that these deserve a place along side property interests: "Relational interests (interests in relations with other persons) are distinct interests. They extend beyond the personality and are not symboliced by any tangible thing that can legitimately be called property."

If the law is willing to compensate for injury to property interests, how can it reasonably refuse to do so for injury to these relational interests?

Once it has been said that the law should compensate spouses for the injury to their marital interests, there is no need to discuss whether compensation should be provided for both non-pecuniary and pecuniary losses. By allowing recovery for injury to marital interests, one is necesarily saying that there will be compensation for non-pecuniary losses and just as courts must deliberate in cases where general damages are claimed before arriving at an appropriate amount, so too will they have to do so in assessing damages claimed for loss of consortium caused by injury.

For the reasons given above, it is recommended that the Alberta Government should provide both spouses with a statutory right of action to claim for damages for loss of consortium caused by injury to the other spouses, whether intentional or negligent. The Government of Alberta, in fact, implemented this recommendation in 1973 , but without apparently giving much thought to it.

\section{CONCLUSION}

In 1973 a married woman in Alberta was given a statutory right of action for damages against a person who enticed away her husband, harboured him, committed adultery with him or injured him. In giving a married woman such a right of action, one which her husband had enjoyed since 1927, the Government gave little thought as to why she should have it. It is submitted that had the Government done a more complete analysis, it would have come to the conclusion that neither husband nor wife should have a right of action against a person who entices away, harbours or commits adultery with the other spouse, but that both spouses should have a right of action for loss of consortium where the other spouse has been injured by a third party. Had the Government implemented these changes, it would have recognized that the protection of marital relationships lies both with the individual and with the State, and thus would have approached a more valid interpretation of marriage.

81. Id., at 88. 